\title{
Effect of brazing temperature on microstructure and mechanical properties of dissimilar joints of titanium/stainless steel joint brazed by Al interlayer
}

\author{
Wpływ temperatury spajania na mikrostrukturę \\ oraz właściwości mechaniczne połączeń \\ tytan/stal nierdzewna wykonanych przy użyciu aluminium
}

\begin{abstract}
In present investigation diffusion brazed joints between titanium (Grade 2) and stainless steel (X5CrNi18-10) using $100 \mu \mathrm{m}$ thick aluminum foil as a filler metal were produced at the temperature range from 550 to $700{ }^{\circ} \mathrm{C}$ for $60 \mathrm{~min}-$ utes under $2 \mathrm{MPa}$ bonding pressure in vacuum. The effect of temperature on the microstructure was investigated using light optical microscopy and scanning electron microscopy equipped with an energy dispersive X-ray system (EDS) to determine chemical composition of joint. The $\mathrm{FeAl}_{3}$ and $\mathrm{Fe}_{2} \mathrm{Al}_{5}$ intermetallic layers were observed at the stainless steel-aluminum interfaces. At the aluminum-titanium interfaces $\mathrm{TiAl}, \mathrm{TiAl}_{2}, \mathrm{TiAl}_{3}$ intermetallic layers were identified. The thickness of the reaction products increases with increase in the joining temperature. The highest shear strength (91 MPa) was achieved for samples prepared at $600{ }^{\circ} \mathrm{C}$.
\end{abstract}

Keywords: diffusion brazing; titanium; stainless steel; microstructure; mechanical properties

\section{Streszczenie}

Lutowanie dyfuzyjne zostało wykonane pomiędzy tytanem (Grade 2) a stalą nierdzewna (X5CrNi18-10) z wykorzystaniem foli aluminiowej o grubości $100 \mu \mathrm{m}$. Lutowanie zostało przeprowadzone w temperaturach od 550 do $700{ }^{\circ} \mathrm{C}$ w czasie 60 minut pod dociskiem $2 \mathrm{MPa}$ w próżni. Wpływ temperatury na mikrostrukturę połączenia został przebadany na mikroskopie optycznym oraz elektronowym mikroskopie skaningowym wyposażonym w mikroanalizator rentgenowski (EDS). Na granicy stali nierdzewnej z aluminium wydzieliły się warstwy faz $\mathrm{FeAl}_{3}$ oraz $\mathrm{Fe}_{2} \mathrm{Al}_{5}$. Struktura załącza od strony tytanu składała się oraz warstw faz międzymetalicznych TiAl, $\mathrm{TiAl}_{2}, \mathrm{TiAl}_{3}$. Grubość warstw reakcyjnych rosła wraz ze wzrostem temperatury lutowania. Najwyższą wytrzymałość (91 MPa) uzyskano podczas testów ścinania technologicznego połączeń lutowanych w temperaturze $600{ }^{\circ} \mathrm{C}$.

Słowa kluczowe: lutowanie dyfuzyjne; tytan; stal nierdzewna; mikrostruktura; właściwości mechaniczne

\section{Introduction}

In recent years, considerable interest has been given to titanium and its alloys because of its unique properties such as high strength, toughness, erosion resistance and low thermal conductivity and density [1,2]. Nuclear, chemical, aerospace and space industries strongly demand dissimilar joints of titanium and titanium alloys to austenitic stainless steel due to good corrosion resistance and satisfactory mechanical behavior [3]. This type of joints finds implementations in satellite cooling system, in the reprocessing plant at Kalpakkam in electrolytic dissolver unit, as well as in subassemblies of nuclear reactors and aircraft engines $[4,5]$. Traditional fusion welding of dissimilar materials results in different problems like distortion of components, formation of stress concentration sites, development of chemical heterogeneities and a number of intermetallic phases that are formed in the weld pool. Since, titanium and its alloys are chemically reactive, they are very difficult to weld, because they can easily pick up nitrogen and oxygen from the atmosphere [6]. Hence, diffusion brazing process is recommended for materials with extremely different physical and mechanical properties [7]. Existing literature reports that direct joining between titanium and stainless steel results in formation of numerous intermetallic phases due to the limited solubility of iron in titanium and these intermetallics deteriorate the bond strength. In addition, high internal stresses are formed because of a large difference of linear expansion

mgr inż. Bartłomiej Szwed, dr hab. inż. Marek Konieczny - Kielce University of Technology.

Autor korespondencyjny/Corresponding author: bartlomiej_szwed@o2.pl 
and heat transmission coefficient between titanium and stainless steel which lead to a bonding crack. Therefore indirect joining by adding interlayer metal is now largely used [8]. The use of appropriate intermediate materials can also inhibit diffusion of undesired elements [9]. Nickel, copper, silver and their alloys were also used as intermediate ma-

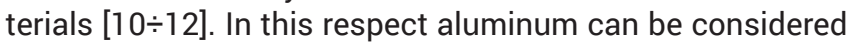
as a useful interlayer due to the lowering of brazing parameters for the diffusion brazing and aluminum has certain erosion resistance and excellent plasticity [13]. Diffusion brazing depends on three major parameters like temperature, holding time and pressure.

The present investigation reports the influence of the brazing temperature on the microstructure, shear strength and hardness of diffusion brazing joints of titanium and stainless steel with aluminum as an intermediate material.

\section{Experimental procedure}

The base materials used for a dissimilar joints were commercially pure titanium (Grade 2) and stainless steel (X5CrNi18-10), both received in the form of cylindrical rods having $8 \mathrm{~mm}$ diameter and $2000 \mathrm{~mm}$ length, and aluminum foil of $100 \mu \mathrm{m}$ thickness. The nominal chemical composition at room temperature of these materials are given in table I.

Cylindrical specimens of $8 \mathrm{~mm}$ diameter and $10 \mathrm{~mm}$ length were machined from the titanium and stainless steel rods. The circular profile discs with $8 \mathrm{~mm}$ diameter were excised from the aluminum foil. The mating surfaces of the samples were kept in contact with steel clamp and inserted in a vacuum chamber. The bonding pressure of $2 \mathrm{MPa}$ along the longitudinal direction was applied at room temperature. Diffusion brazing was carried out in a vacuum furnace Czylok PRC 77/1150 at the temperature range from 550 to $700^{\circ} \mathrm{C}$ for 60 minutes with a vacuum of $10^{-3} \mathrm{~Pa}$. The samples were cooled with the furnace. The specimens for metallographic examination were cut out longitudinally and their surfaces were prepared by conventional techniques, using sandpapers of 180 to 1200 grit, alumina suspension with a grain size of $0.5 \mu \mathrm{m}$ and colloidal silica with a grain size of $0.05 \mu \mathrm{m}$. The titanium side and the joint were etched in an aqueous solution of $95 \mathrm{ml} \mathrm{H} \mathrm{H}_{2}$ and $5 \mathrm{ml} \mathrm{HF}$. The samples were observed in a light microscope Nikon Eclipse MA200 to reveal the structural changes due to diffusion. The polished surfaces of the brazed couples were also examined in a scanning electron microscope (SEM) JEOL JMS-5400 to obtain finer structural details in the diffusion zone. The composition of the reaction layers was determined in atomic percent using Oxford Instruments ISIS energy dispersive X-ray spectrometer (EDS) attached to the SEM. The results of the EDS analysis were compared with the binary phase diagrams of basic components. The shear strength of the brazed joints was evaluated at room temperature using a LabTest 5.20SP1 testing machine at a crosshead speed of $10 \mathrm{~mm} / \mathrm{min}$. Five samples were tested for each processing parameter. The Matsuzawa MMT microhardness tester was used to examine the hardness along the cross-section of the joints under load of $0.196 \mathrm{~N}$ for a dwelling time of 10 seconds.

\section{Results and discussion}

The joints were successfully formed for all temperatures, and certain amount of diffusion occurs between the interlayer and the two substrates. The light micrographs of the brazed assemblies are shown in figure 1 From the micrographs, it can be seen that the base materials have been well pressed to the aluminum filler metal giving a consistent joint on both sides. No cracks and voids were observed on the interface between the brazed materials. The structures of the joints varied importantly depending on joining temperature. The wide of the diffusion zone on the boundaries with joined materials increase with an increase in brazing temperature. Since the diffusion bonding temperature is lower than the beta phase transformation, the titanium site is characterized by the a Ti structure. In addition, aluminum is an a stabilizing element and it raises the $\beta$ phase transformation temperature of $\mathrm{Ti}$ [1].

The diffusion zone at the SS-Al interface is much larger compared to the Ti-Al side. Appearance of particles have been observed in aluminum interlayer in samples achieved at the highest brazing temperature. In order to further characterize the reaction layers of the joint, a SEM images were performed on the reaction layers (Fig. 2). The presence of thin layer consisted of 99.08 at. \% $\mathrm{Ti}$ and 0.92 at. \% $\mathrm{Al}$ was observed between Ti-Al side at the $550{ }^{\circ} \mathrm{C}$ processing temperature, it appears to be solid solution of aluminum in titanium. At the temperature range of 600 to $650{ }^{\circ} \mathrm{C}$ appeared reaction layer adjacent to the titanium side that consisted of 68.62 at. \% Al and 31.38 at. \% Ti. According to the Ti-Al binary phase diagram it is likely a $\mathrm{TiAl}_{2}$ intermetallic compound. The layer of regular particles containing 74.83 at. \% Al and 25.17 at. \% $\mathrm{Ti}$ and 49.26 at. \% Al and 50.74 at. $\% \mathrm{Ti}$ have been found at the aluminum/titanium interface when brazing temperature was $700{ }^{\circ} \mathrm{C}$. This composition corresponds to the $\mathrm{TiAl}_{3}$ and TiAl intermetallic phase. Regardless to the process temperature at the SS-Al side continuously formed layer consisted of 74.39 at. \% Al and 17.89 at. $\%$ Fe with small amounts of $\mathrm{Cr}$ (5.45 at. \%) and $\mathrm{Ni}$ (2.27 at. $\%)$. According to the Fe-Al binary phase diagram it is likely a $\mathrm{FeAl}_{3}$ intermetallic compound with the addition of $\mathrm{Cr}$ and $\mathrm{Ni}$. At the temperature range of 600 to $650{ }^{\circ} \mathrm{C}$ alongside with the $\mathrm{FeAl}_{3}$ has formed another layer consisted of 72.94 at. \% Al and 20.82 at. \% Fe with small amounts of $\mathrm{Cr}$ (4.96 at. \%) and $\mathrm{Ni}\left(1.28\right.$ at. \%). It seems to be $\mathrm{Fe}_{2} \mathrm{Al}_{5}$. When the brazing temperature increased to $700{ }^{\circ} \mathrm{C}$ two reaction layers were observed between the stainless steel and aluminum interface.

The first reaction layer adjacent to the stainless steel side consisted 71.06 at. \% $\mathrm{Al}$ and 22.39 at. \% Fe with small amounts of $\operatorname{Cr}$ (6.55 at. \%). Under the first layer, second layer adjacent to aluminum has a composition of 79.43 at. \% Al and 16.27 at. \% Fe with small additions of $\mathrm{Cr}$ (3.09 at. \%) and $\mathrm{Ni}$ (1.21 at. \%). According to the chemical analyses and the Fe-Al binary phase diagram, it can be assumed that the phases present in the form of layers at the SS-Al interface are $\mathrm{FeAl}_{3}$ with an amount of $\mathrm{Cr}$ and $\mathrm{Ni}$ admixtures and the second one is also $\mathrm{FeAl}_{3}$ but enriched with Al. Additionally, in this temperature the irregular shaped

Table I. Chemical compositions of the base materials (accordingly to certificates) Tablica I. Składy chemiczne materiałów bazowych (według certyfikatów)

\begin{tabular}{|c|c|c|c|}
\hline Material & $\begin{array}{l}\text { Titanium } \\
\text { (Grade 2) }\end{array}$ & $\begin{array}{l}\text { Stainless steel } \\
\text { (X5CrNi 18-10) }\end{array}$ & $\begin{array}{l}\text { Aluminum } \\
(\mathrm{Al} 99,5)\end{array}$ \\
\hline $\begin{array}{l}\text { Chemical composition } \\
\text { (wt. \%) }\end{array}$ & $\begin{array}{c}\text { Ti: } 99.654, \text { Fe: } 0.171, \text { C: } 0.024, \\
\text { N: } 0.008,0: 0.142, H: 0.001\end{array}$ & $\begin{array}{l}\text { Fe: } 71.495, \text { C: } 0.025, \mathrm{Mn}: 1.460, \\
\text { Si: } 0.390, \text { P. } 0.038, \text { S: } 0.012 \\
\text { Cr: } 18.150, \text { Ni: } 8.050, \text { Mo: } 0.380\end{array}$ & $\begin{array}{l}\text { Al: } 99.53, \text { Fe: } 0.21, \text { Si: } 0.16 \text {, } \\
\text { Zn: } 0.05, \text { Cu: } 0.03, \text { Ti: } 0.02\end{array}$ \\
\hline
\end{tabular}


a)

X5CrNi18-10

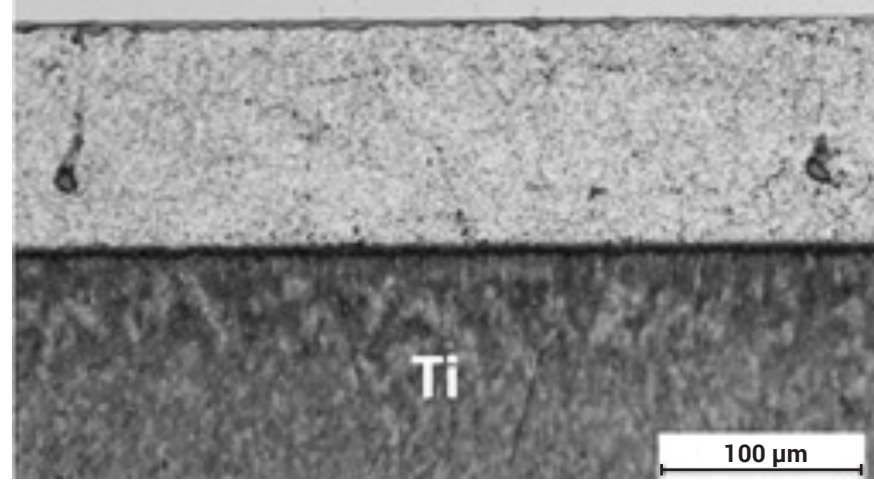

c)

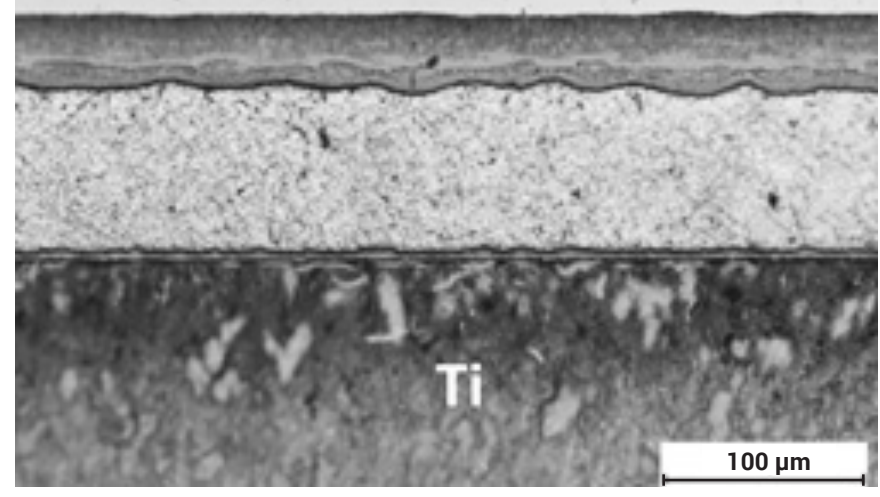

b)

X5CrNi18-10

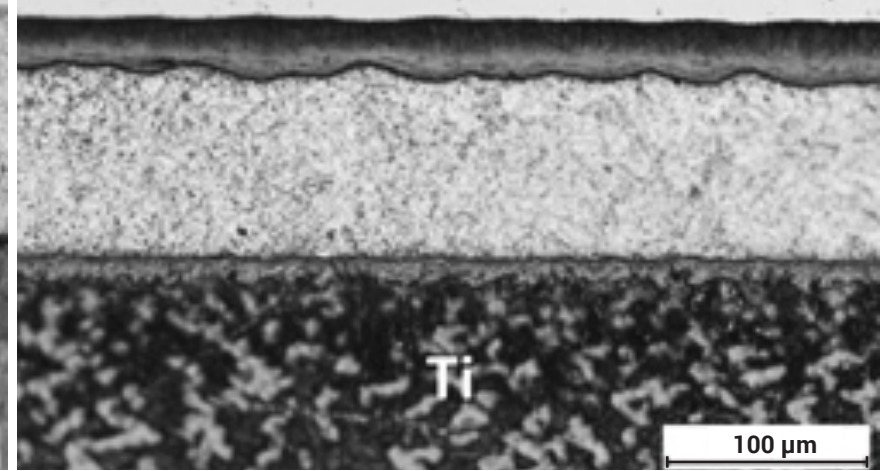

d)

X5CrNi18-10

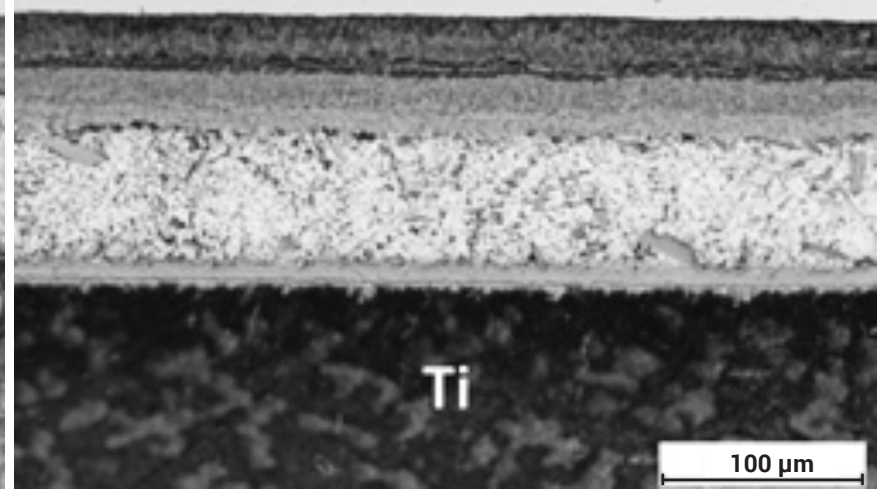

Fig. 1. Light micrograph of the joints prepared at a) $550^{\circ} \mathrm{C}$, b) $\left.600{ }^{\circ} \mathrm{C}, \mathrm{c}\right) 650^{\circ} \mathrm{C}$, d) $700^{\circ} \mathrm{C}$ for 60 minutes

Rys. 1. Mikrografa świetlna połączeń wykonanych w temperaturze: a) $550^{\circ} \mathrm{C}$, b) $600^{\circ} \mathrm{C}$, c) $650^{\circ} \mathrm{C}$, d) $700^{\circ} \mathrm{C}$ przez 60 minut

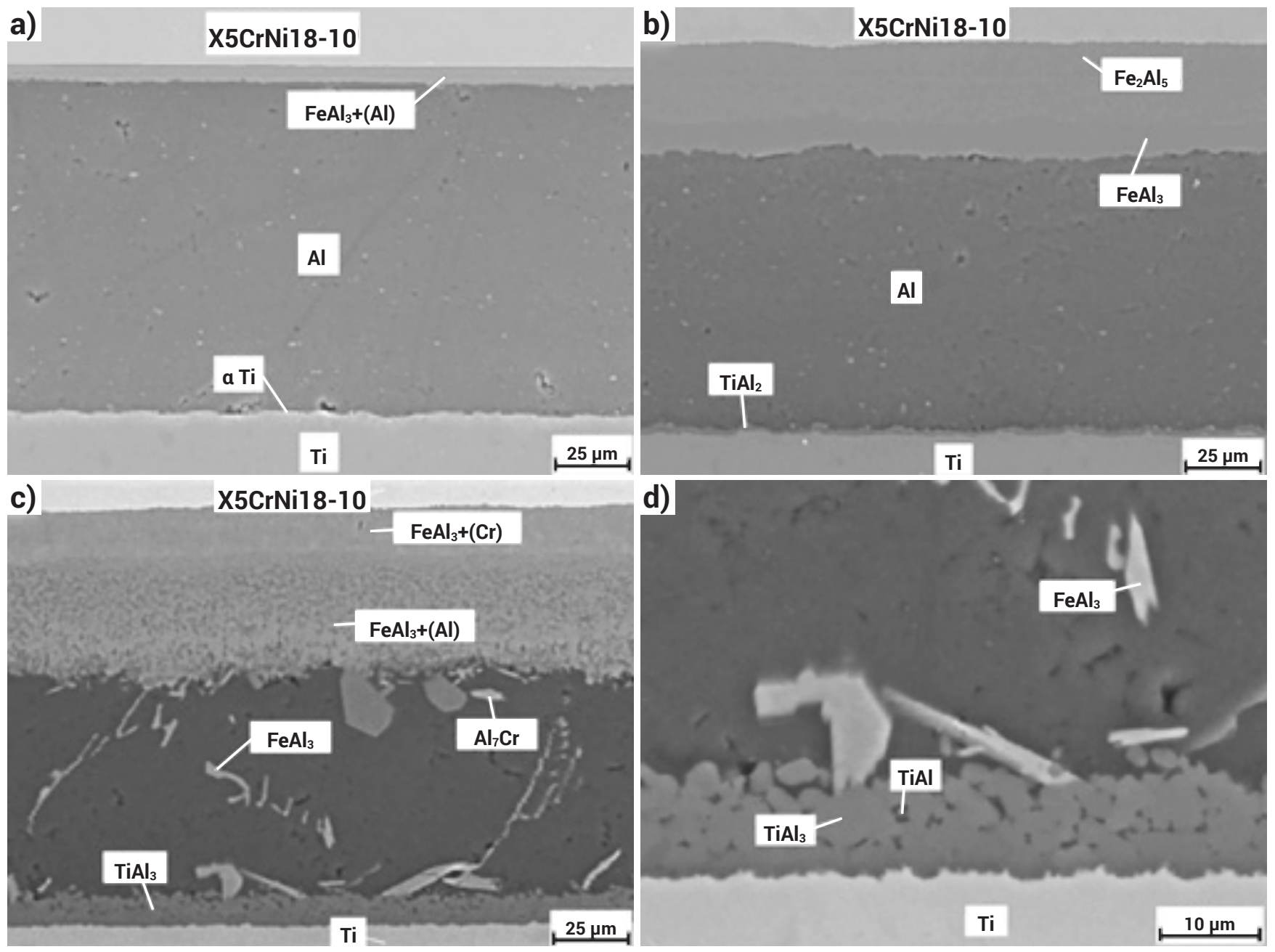

Fig. 2. SEM images of the joints processed at a) $550^{\circ} \mathrm{C}$, b) $600{ }^{\circ} \mathrm{C}$, c) $650^{\circ} \mathrm{C}$, d) $700^{\circ} \mathrm{C}$ for 60 minutes

Rys. 2. Zdjęcia SEM połączeń przetwarzanych w temperaturze: a) $550^{\circ} \mathrm{C}$, b) $600{ }^{\circ} \mathrm{C}$, c) $650^{\circ} \mathrm{C}$, d) $700^{\circ} \mathrm{C}$ przez 60 minut 
particles containing 86.71 at. \% $\mathrm{Al}$ and 8.72 at. \% $\mathrm{Cr}$ with amounts of $\mathrm{Ti}(1.89$ at. \%) and $\mathrm{Fe}$ (2.68 at. \%) have been observed in aluminum matrix. It appears to be $\mathrm{Al} 7 \mathrm{Cr}$ intermetallic phase.

Microhardness measurements of titanium substrate, interface zone and steel substrate were performed for all processed samples. The maximum hardness values in the range of 506 to $807 \mathrm{HV}$ were recorded at the stainless steelaluminum interface due to the formation of the $\mathrm{FeAl}_{3}$ and $\mathrm{Fe}_{2} \mathrm{Al}_{5}$ intermetallic phases. In the middle of the joints hardness values were in the range of $28-44 \mathrm{HV}$. At the titaniumaluminum side the hardness reach values in the range of 197 to $220 \mathrm{HV}$. An increase in the bonding temperature resulted in an increase in the hardness of the joints what was due to an increased formation of hard Fe-Al, Al-Cr and Ti-Al based intermetallic phases.

The room temperature shear strength of the diffusion brazed joints with change in brazing temperature are shown in figure 3.

It can be seen that when the brazing temperature was 550 ${ }^{\circ} \mathrm{C}$ the shear strength of the diffusion couple was low and reached a value of $54 \mathrm{MPa}$, due to the thin diffusion zone at the stainless steel-aluminum interface. With the increase in brazing temperature to $600^{\circ} \mathrm{C}$, the shear strength increases and reach it maximum value of $91 \mathrm{MPa}$. At this processing temperature the diffusion between the mating surface is larger compared to that of lower temperature and the width

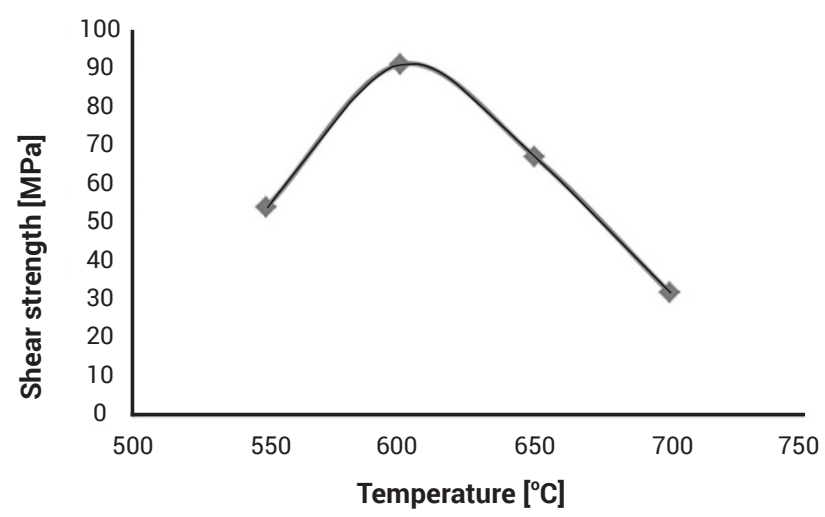

Fig. 3. Shear strength for diffusion brazed joints processed for $60 \mathrm{~min}$ Rys. 3. Wytrzymałość na ścinanie dla połączeń lutowanych dyfuzyjnie przetwarzanych przez $60 \mathrm{~min}$

of intermetallics formed at both the interfaces were smaller compared to that of higher brazing temperatures. With a further rise in brazing temperature, the width of intermetallic layers formed at the boundaries of joined materials, increases significantly causing that the shear strength gradually drops respectively 67 and $32 \mathrm{MPa}$ for the samples achieved at 650 and $700{ }^{\circ} \mathrm{C}$. All samples were separated on the boundary between stainless steel-aluminum side, where formed $\mathrm{Fe}_{2} \mathrm{Al}_{5}$ and $\mathrm{FeAl}_{3}$ intermetallic phases.

\section{Conclusions}

The investigation show that it is possible to join titanium with stainless steel by aluminum interlayer. Diffusion brazing temperature is a critical factor controlling the microstructure of specimens. The diffusion zone on the boundaries of joined materials becomes wider with the increase in temperature. The phases present in joints were intermetallics and solid solutions based on intermetallic phases or substrate metals. The thicknesses of the intermetallic layers increases with the increase in the brazing temperature. The aluminum interlayer of $100 \mu \mathrm{m}$ thickness effectively blocked the diffusion of titanium to stainless steel side, thus prevented from formation of Fe-Ti intermetallic phases on the boundaries of joined materials. Microhardness analysis show that the Ti-Al based intermetallic formation at Ti-Al interface has lower hardness than the Fe-Al base intermetallic at stainless steel-aluminum interface. The hardness values of intermetallic layers increase with the increase in brazing temperature due to diffusion of admixtures to intermetallic phases. The maximum shear strength of $91 \mathrm{MPa}$ was obtained for the diffusion brazed joints processed at $600{ }^{\circ} \mathrm{C}$. The further increase in brazing temperature increases the volume faction of intermetallic formed at the diffusion interfaces, hence joints strength gradually drops.

\section{References}

[1] J. R. Davis: ASM Handbook, Volume 02 - Properties and Selection: Nonferrous Alloys and Special-Purpose Materials, 2nd ed. Portland, Asm International Handbook Committee, 1990.

[2] M. Ghosh, S. Chatterjee: Diffusion bonded transition joints of titanium to stainless steel with improved properties, Materials Science and Engineering A, vol.358 (1-2), pp. 152-158, 2003.

[3] F. Möller, M. Grden, C. Thomy, F. Vollertsen: Combined laser beam welding and brazing process for aluminum titanium hybrid structures, Physics Procedia, vol.12 pp. 215-223, 2011.

[4] Lee M.K., J.J. Park, G.J. Lee, D.W. Kim, C.H. Lim, C.K. Rhee, S.J. Hong: Corrosion of Ti-STS dissimilar joints brazed by a $\mathrm{Ag}$ interlayer and $\mathrm{Ag}-\mathrm{Cu}-(\mathrm{Pd})$ alloy fillers, Journal of Nuclear Materials, vol.409 (3), pp. 183-187, 2011.

[5] W. Yao, A. Wu, G. Zou, J. Ren: Formation process of the bonding joint in Ti/Al diffusion bonding, Materials Science and Engineering A, vol.480 (1), pp. 456-463, 2008.

[6] Z. Ma, C. Wang, H. Yu, J. Yan, H. Shen: The microstructure and mechanical properties of fluxless gas tungsten arc welding-brazing joints made between titanium and aluminum alloys, Materials and Design, vol. 45 pp. 72-79, 2013.

[7] A. Elrefaey, W. Tillmann: Microstructure and mechanical properties of brazed titanium/steel joints, Journal of Materials Science, vol. 42, pp. 9553-9558, 2007.
[8] S. Kundu, D. Roy, S. Chatterjee, D. Olson, B. Mishra: Influence of interface microstructure on the mechanical properties of titanium/17-4 PH stainless steel solid state diffusion bonded joints, Materials and Design, vol.37, pp. 560-568, 2012.

[9] M. Konieczny, R. Mola: Fabrication, microstructure and properties of laminated iron-intermetallic composites, Steel Research International, vol.79, pp. 499-505, 2008.

[10] B. Szwed, M. Konieczny: Microstructure and Mechanical Properties of Joints of Titanium with Stainless Steel Performed Using Nickel Filler, Archives of Metallurgy and Materials, vol.61 (2B), pp. 997-1001, 2016.

[11] B. Szwed, M. Konieczny. Influence of diffusion bonding parameters on the structure and properties of titanium and stainless steel joints with copper interlayer, Journal of Achievements in Materials and Manufacturing Engineering, vol. 67 (1), pp. 21-25, 2014.

[12] M. Balasubramanian: Characterization of diffusion-bonded titanium alloy and 304 stainless steel with $\mathrm{Ag}$ as an interlayer, International Journal of Advanced Manufacturing Technology, vol.82 (1), pp.153-162, 2008.

[13] S. Kundu, S. Chatterjee: Interface microstructure and strength properties of diffusion bonded joints of titanium-Al interlayer $-18 \mathrm{Cr}-8 \mathrm{Ni}$ stainless steel, Materials Science and Engineering A, vol.527 (10-11), pp. 27142719, 2010. 